\title{
A Political Realist Notion of Public Reason*
}

\author{
Bertjan Wolthuis
}

The attraction of political liberalism's notion of public reason is that it provides an explanation and evaluation of political argumentation. ${ }^{1}$ It views political argumentation as a reason-giving practice taking place between equal, free, and reasonable citizens who may perhaps disagree about what is valuable in life, but who will agree, it is assumed, about what is political or public reason, because it is the reason consistent with this political justice of equal freedom for all. This body of public arguments is available and acceptable to citizens and underlies the laws of which these citizens can therefore view themselves as authors - governing their conduct.

The basic agreement on justice on which this notion of public reason rests is precisely what contemporary critics of mainstream liberalism find not attractive about the idea of public reason. According to these political realists, actual political experience, where citizens may disagree about the fundamentals of justice, differs in important respects from this idealized picture of politics. ${ }^{2}$ A proper understanding of political argumentation is not possible if this kind of disagreement is not taken into account.

So what we have here is a notion with an explanatory and critical potential that cannot be fully released, according to these critics, because the model of politics it presupposes does not match real politics, as seen from the realist's point of view. The problem this article now aims to solve is this: What notion of public reason would be compatible with the realist's point of view? ${ }^{3}$

While political realists have stressed the value of political procedures and have heralded the virtues of fairness and compromise, ${ }^{4}$ these topics have not yet been framed in terms of public reason. The obvious explanation is that the liberal notion of public reason has always been so closely linked to agreement about lib-

* I thank Toni van Gennip for his assistance in the first stage of this project. I thank Raf Geenens, Anthony Duff, and two anonymous reviewers for valuable feedback.

1 With 'political liberalism' I refer to John Rawls' constructivist theory of justice and legitimacy. In The Law of Peoples, Rawls refers to his theory (extended in that work to the international realm) as 'political liberalism'. See John Rawls, The Law of Peoples (Cambridge, Mass.: Harvard University Press, 1999), 9: '[...] it is important to see that the Law of Peoples is developed within political liberalism [...].'

2 Some of these critics are Stuart Hampshire, Jeremy Waldron, Glen Newey, and Matt Sleat. See the references to their work in this article.

3 The question does not presuppose the truth or correctness of the realist criticism. The article does not take sides in the discussion between liberals and realists. The idea is that addressing the above question sheds new light on the discussion.

4 See particularly: Stuart Hampshire, Justice as Conflict (London: Duckworth, 1999), Jeremy Waldron, Law and Disagreement (Oxford: Oxford University Press, 1999). 
eral standards, that the idea of an alternative, realist notion of public reason must have been considered unthinkable.

But perhaps, it is not. Perhaps, it requires an altogether different view of political argumentation. In this article, I propose to take a look at political argumentation from the point of view of classical rhetoric. The reason for this proposal is that these ancient manuals on rhetoric do not presuppose agreement (as opposed to liberalism) and express at the same time a strong commitment to forms of public argumentation and procedure (a commitment shared by both contemporary liberals and contemporary realists). Classical rhetoric conceptualizes public reasoning against a background of fundamental political disagreement.

My claim in this article is not that classical rhetoricians are predecessors of what we call today political realists. The argument is limited to the claim that the notion of public reason reconstructed from rhetorical texts is compatible with the political realist framework. This argument involves two separate claims. The first is that a notion of public reason can be reconstructed from classical manuals of rhetoric. To argue for this claim (section 4), I obviously need to examine rhetoric - I will draw particularly on Aristotle's - but I also need to explain what a notion of public reason in general is. We have to know in advance what to look for. So the question addressed (in section 3 ) is: What are the general features of a notion of public reason? The second claim is that the recovered notion of rhetorical public reason is compatible with the political realist framework. To argue for that claim, it is necessary to reconstruct that framework (section 2) and assess whether the rhetorical notion can be added to it, as a component. Since political realism is a series of criticisms levelled against contemporary liberal thought, I will start with a brief survey of the theory most realists take as target: John Rawls' political liberalism (section 1).

The overall objective of the article is to develop the political realist position with respect to political argumentation. The realist position highly values political procedures and practices of discussion, contestation, and justification. A notion of public reason may complete this position. The aim of this article is not to defend or attack political realism. The aim is to enhance our understanding of the theory by adding a notion that has so far received little attention. ${ }^{5}$

\section{Political liberalism}

With 'political realism', I do not refer in this article to a specific political theory, designed by one author or one group of authors, working closely together on a program. Political realism is understood here, as it usually is, as a collection of

5 Ancient rhetoric and liberalism have been confronted before (for instance, Gary Remer, 'Political Oratory and Conversation. Cicero versus Deliberative Democracy,' Political Theory 27 (1999): 39-64 and Gary Remer, 'Two Models of Deliberation. Oratory and Conversation in Ratifying the Constitution,' The Journal of Political Philosophy 8 (2000): 68-90) but not in terms of public reason, as far as I can see. 
often related but not necessarily consistent criticisms of contemporary mainstream liberal thought. ${ }^{6}$ The implication is that political realism cannot be properly introduced, let alone structured, without a brief overview of the target of these criticisms. John Rawls' work is outlined in this section to give this target a more specific form and also to prepare the idea of public reason below (section 3 ). We will see in section 2 that political realism opposes each of the following elements of political liberal thought.

Political liberalism is a form of social contract theory. Social contract theory generally frames the question what reasons we have to accept and obey positive law in terms of the following thought experiment: What reasons for the establishment of society would convince individuals to leave the state of nature? Rawls carries this kind of theory to a "higher level of abstraction'7 because he starts with the preceding argument for principles of justice that should inform the argument for the subsequent establishment of society.

Rawls' work abstracts from radical disagreement about justice and from issues of non-compliance with rules specified by the selected principles. It is 'ideal theory' in this sense. The assumption is that society is 'well ordered' by its principles of justice: that all citizens accept and comply with the principles of justice and that all citizens know that all citizens accept and comply with these principles that govern the basic structure of their society. ${ }^{8}$ This ideal character of the theory enables Rawls to focus exclusively on the selection and justification of principles of justice. The underlying idea is that we have a clear view of what are injustices and share a basic understanding of justice. ${ }^{9}$

6 An overview of the criticisms is presented in William Galston, 'Realism in Political Theory,' European Journal of Political Theory 9 (2010): 385-411. Galston views realism as 'a kind of community stew where everyone throws something different into the pot' (p. 386). I think the picture is adequate. I agree that this stew has a particular flavour or, as Galston writes, mixing metaphors now, a particular 'theme'. The theme is: 'the belief that high liberalism represents a desire to evade, displace or escape from politics' (p. 386). Notice that this theme is formulated as a criticism. Political realism is first and foremost a critical analysis of liberalism, according to Galston. I agree with Galston here. The implication is that I need to start with liberalism in this article. Galston's image of the stew may, although largely adequate, convey on the other hand the picture, which is clearly false, that all the different theoretical criticisms and proposals (ingredients) advanced by realists go together harmoniously. Those labelled as realists disagree, as is to be expected, on several points. In this article, I do not focus on these disagreements. My concern is to show that the rhetorical notion of public reason fits the rough, general realist framework. This framework must somehow be constructed - it is not given. My choice is to construct the theory as a criticism of a particular political theory, John Rawls' political liberalism. Other reconstructions are of course possible. I do not think that alternative reconstructions would affect the conclusion of the article.

7 John Rawls, A Theory of Justice, Revised Edition (Cambridge, Mass.: Harvard University Press, 1999 (1971)), 10.

8 Rawls, $A$ Theory of Justice, 4-5.

9 Rawls, A Theory of Justice, 5, about the agreement about the concept of justice, and at p. 17 and p. 18 , about the 'confidence' about injustices. 
The position from which we are supposed to think about justice and its application to social orders is not to be thought of as a hypothetical state of nature. The idea is instead that we, equal and free citizens of a democratic society, can and should enter this 'original position' any time we discuss matters concerning justice. Viewing citizens as free and equal members of society is the 'fundamental idea' of the theory. ${ }^{10}$ It answers the very first question of a theory of justice, the question who should answer the question: What is justice? ${ }^{11}$ Since this feature that we should enter this position any time we discuss matters of justice - would allow us to select principles of justice that would benefit us (but not others), Rawls asks us to imagine that we are located in this position behind a 'veil of ignorance' that hides from view our place in society, our natural abilities, and our views about what is valuable in life.

The idea is that once we imagine to be in this original position with its veil of ignorance and discuss matters of justice, we are approaching justice from a fair, moral point of view. It is fair, moral, to place ourselves in the situation of each and every one and select principles that are equally acceptable to all. ${ }^{12}$ In the original position, the parties representing equal and free citizens select two specific principles of welfare liberalism. In Political Liberalism, the argument is that laws are justified as legitimate if these are shown to be 'in accordance with a constitution the essentials of which all citizens as free and equal may reasonably be expected to endorse'. ${ }^{13}$ This process of justification is described in terms of public reason. Since citizens are thought of as free and equal, they also need to be thought of as insisting upon the public justification of the laws regulating their cooperation, and this public justification involves the reference in public by public officials to reasons acceptable to free and equal citizens. This last phrase indicates that these reasons cannot be only part of some private notion of what constitutes a valuable life, from what Rawls refers to as a comprehensive doctrine. These reasons must be political, part of the shared political culture of a liberal democracy. If public reason is used, the status of citizens as free equals is respected and legitimacy is enhanced. The legitimacy of laws in a form of representative government

10 John Rawls, 'Justice as Fairness: Political not Metaphysical,' in Collected Papers, ed. Samuel Freeman (Cambridge, Mass.: Harvard University Press, 1999), 394.

11 The implication of this 'fundamental idea' is that it does not do justice to the theory to shelve it as a 'purely recipient-oriented' theory of distributive justice. See Rainer Forst, 'Zwei Bilder der Gerechtigkeit,' in Kritik der Rechtfertigungsverhältnisse. Perspektiven einer kritischen Theorie der Politik, ed. Rainer Forst (Frankfurt am Main: Suhrkamp, 2011), 45. The characterization 'purely recipient-oriented' is from Thomas Pogge, 'The Incoherence between Rawls's Theories of Justice,' Fordham Law Review 72 (2004): 1740.

12 As has been noticed, the imaginary parties in this original position are not able to act or think morally themselves; they can act and think only rationally. Jürgen Habermas thinks this disqualifies the original position as a model of the moral point of view. See Jürgen Habermas, 'Versöhnung durch öffentlichen Vernunftgebrauch,' in Die Einbeziehung des Anderen, ed. Jürgen Habermas (Frankfurt am Main: Suhrkamp, 1996), 69-70. I think Rawls' idea is that imagining to be a party in this situation is a fruitful way to model the moral point of view.

13 John Rawls, Political Liberalism (New York: Columbia University Press, 1993), 137. 
where free and equal citizens rule as a collective depends on this use of public reason. ${ }^{14}$

A society governed in this way by principles of justice will become stable, Rawls hypothesizes, since practices of public reasoning will turn modus vivendi agreements about principles of justice step by step into what Rawls refers to as an 'overlapping consensus'. ${ }^{15}$ The object of this consensus is moral (a political conception of justice), and the foundation is also moral; the political conception is based on moral reasons (political values such as those organized in the idea of society as a system of cooperation between free and equal citizens). The comprehensive doctrines overlap on both these points: the political conception and the reasons that support this conception are part of these doctrines. This substantial overlap implies that a change in the balance of power between the (citizens who endorse the) various comprehensive doctrines cannot affect the consensus and thereby society's stability. Rawls' view is that 'three centuries of democratic thought and developing constitutional practice ${ }^{16}$ imply that the support for a conception of justice underlying a democracy's constitution can no longer be adequately portrayed in the cynic terms of a modus vivendi. ${ }^{17}$

\section{Political realism}

Political realism is now introduced as a series of interrelated criticisms of these central elements of political liberalism. I also indicate the alternatives that follow in the slipstream of these counterarguments. ${ }^{18}$

\section{Well-ordered society}

Political realists dismiss Rawls' basic choice to theorize about justice against the background of a well-ordered society, a society where citizens accept the same principles of justice that govern their society. While Rawls thinks this assumption is not too far removed from political practice - he thinks we all agree about the general concept of justice - political realists refuse to take this for granted. Jeremy Waldron argues that the assumption begs the question politicians in the real world are asked to address. Glen Newey explains that in Rawls' well-ordered society, there is no place for politics, if politics is understood to involve also

14 On the idea of public reason see John Rawls, 'The Idea of Public Reason Revisited,' in Rawls, Collected Papers, chapter 26.

15 John Rawls, 'The Idea of an Overlapping Consensus', in Rawls, Collected Papers, chapter 20.

16 John Rawls, 'The Idea of an Overlapping Consensus', 422.

17 For a more elaborated discussion of this issue, see Bertjan Wolthuis, 'A Political Liberal Approach to the EU. The Legitimacy of EU Intergovernmental Compromises,' Archiv für Rechts- und Sozialphilosophie 102(1) (2016), 40-57.

18 To be sure: it is not possible here to do full justice to the variety and depth of the realist criticisms that have been advanced in the last two or three decades. This need not necessarily frustrate the argument of the article. This argument is limited. The claim is that the notion of public reason to be extracted from texts on rhetoric and dialectic is not incompatible with the political realist framework. 
'debating' justice, not just 'implementing' specific principles of justice. ${ }^{19}$ Politics concerns the selection of a policy or course of action or law in the situation where citizens disagree about which policy, course of action, or law is just, because of the divergent conceptions of justice prevailing in society, Waldron argues. Disagreement about justice is one of the 'circumstances of politics'. The need for a common decision is the other. ${ }^{20}$ The agreement about justice with which Rawls starts already answers the question that legislators need to address: which justice should be done? At the level of political decision making, a party errs when it complains, for instance, that an unjust decision is made:

'When we say that a view which we think incorrect should prevail on political grounds, we approach it not in terms of intrinsic importance or priority, but in light of the basic circumstance of politics - that even on the matters we think most important, a common decision may be necessary despite the existence of disagreement about what that decision should be. The problem defined by that circumstance is the problem of selecting a substantive principle of justice to act on (together) when we disagree about which principles are true or reasonable and which not. To say that in such a case justice is being subordinated to procedural values in political decision making would be to beg the question of which of the positions competing for political support is to be counted as just'. ${ }^{21}$

Waldron describes this point in terms of logical error. One commits 'something of a "category-mistake" in treating justice and fairness as co-ordinate principles, competing on the same level'. ${ }^{22}$

Notice that while Rawls's theory is an example of ideal theory because of its assumption that everyone accepts the same principles of justice, the point of departure of these realist critics is the 'the real world of necessary politics', ${ }^{23}$ which is characterized by radical disagreement about justice. ${ }^{24}$ With this change of perspective, the central question that is raised changes too: "[W] should not be asking questions like "What are the implications of (for example) John Rawls's theory of justice so far as democratic and constitutional procedures are concerned?" Instead we must ask, "What are we to think about democratic and constitutional procedures, given that such procedures have to accommodate a politics for those who differ fundamentally about whether theories like Rawls's are correct?"'. ${ }^{25}$ Many views of justice may gain support in a society, realists think,

Glen Newey, 'Just Politics,' Critical Review of International Social and Political Philosophy 15 (2012): 166. See also the discussion of Rawls' theory in: Glen Newey, After Politics: The Rejection of Politics in Contemporary Liberal Philosophy (London: Palgrave, 2001), chapter 7.

20 Jeremy Waldron, Law and Disagreement (Cambridge: Cambridge University Press, 1999), 160.

21 Waldron, Law and Disagreement, 161.

22 Waldron, Law and Disagreement, 195-6.

23 Stuart Hampshire, Justice is Conflict (London: Duckworth, 1999), 36.

24 Hampshire, Justice is Conflict, 18.

25 Waldron, Law and Disagreement, 3. 
and may conflict at the decision-making level. In these circumstances of politics, there is disagreement and thus technical decision-making rules are needed. 'I am assuming', Hampshire explains, 'that each is making his own case in the real world of necessary politics, following the customary and rule-governed procedures of public argument and decision-making appropriate to such cases in this particular society'.26

\section{Reasonable agreement}

It is instructive to see that, once the assumption of a well-ordered society is rejected, a range of more specific points of criticism becomes intelligible. The first is that radical reasonable political disagreement about justice enters the picture. Liberalism only views disagreement between liberals as reasonable. Realists assume that reasonable persons may reject the central tenets of liberalism. 'Our disagreements about justice are simply too radical, go too deep, for any consensus on the minimum standards of justice to be plausible. It is hard to see how those who advocate liberal egalitarian, communist, and libertarian conceptions of justice, for instance, will be able to agree even on what the minimum standard of a just distribution would be'. ${ }^{27}$ Political liberals may agree that radical disagreement about justice is possible but not radical reasonable disagreement. The difference is that while political liberals view communists and libertarians as unreasonable to the extent that their notions of justice are unacceptable for citizens viewed as free and equal members of a society governed by public law, political realists regard these proposals as possible products of the free use of human reason. The idea that all citizens are to be regarded as equal and free co-operators, on which Rawls bases a political liberalism, as we saw above, excludes obviously non-democratic kinds of rule. ${ }^{28}$ But it also excludes, perhaps less obviously, libertarian views of government, since these reject the idea of public law governing the cooperation between free equals. ${ }^{29}$ However, it does not exclude, on the other side of the political spectrum, liberal democratic variants of socialism (economic systems in which the means of production are publicly owned). ${ }^{30}$ The political liberal point of departure of citizens as equal and free members of society expresses the point on which for liberals (at least of the Kantian kind) everything else rests. ${ }^{31}$ The political realist's aim, however, is precisely to devise a political theory that encom-

Hampshire, Justice is Conflict, 36.

Matt Sleat, 'Legitimacy in a Non-Ideal Key. A Critical Response to Andrew Mason,' Political Theory 40 (2012): 651.

See John Rawls, 'The Idea of Public Reason Revisited,' in The Law of Peoples with “The Idea of Public Reason Revisited”, ed. John Rawls (Cambridge, Mass.: Harvard University Press, 1999), 144.

See John Rawls, Political Liberalism, Lecture VII, para 3.

Rawls, A Theory of Justice, section 42, especially 242.

That it is a key assumption which cannot be rejected is discussed by Burton Dreben who has remarked that 'Rawls is a good enough thinker not to argue against those who do not believe in liberal constitutional democracy.' Burton Dreben, 'On Rawls and Political Liberalism' in The Cambridge Companion to Rawls, ed. Samuel Freeman (Cambridge: Cambridge University Press, 2003), 323. 
passes also the views of liberalism's rivals. ${ }^{32}$ Even the question what politics is, is not something to be decided in theory but is itself a political question. Politics 'is a concept disputes about whose extension themselves fall within its extension', Newey explains. ${ }^{33}$

\section{Political moralism}

Another corollary of lifting the assumption of a well-ordered society is that the moral point of view from which Rawls specifies the principles of justice is now dismissed as an instance of political moralism. As soon as society is viewed as not well ordered, liberalism resurfaces as a kind of theory that represents morality as 'prior to' politics and that considers politics legitimate only if it conforms to this prior morality, as Bernard Williams has explained. Political liberalism turns political theory in effect into 'applied morality'. ${ }^{34}$ The alternative is a political theory that 'gives greater autonomy to distinctively political thought'. ${ }^{35}$ Williams understands politics in this respect as an answer to the situation of domination or oppression. The implication is that politics cannot turn into oppression itself. 'The situation of one lot of people terrorizing another lot of people is not per se a political situation: it is, rather, the situation which the existence of politics is in the first place supposed to alleviate (replace), ${ }^{36}$ Williams admits that if this minimal understanding of politics is a moral conception of politics, 'it does not represent a morality which is prior to politics', but a morality 'inherent in there being such a thing as politics' ${ }^{37}$

\section{Legitimacy}

Given these basic criticisms, it is no surprise that the substantial notion of legitimacy proposed by political liberalism is criticized by realists. This notion is constructed from a presupposed harmony about liberal values or standards, but this is only a 'harmony within the liberal stockade', Stuart Hampshire argues. ${ }^{38}$ Once the view of a harmonious, well-ordered society is substituted for a view of society in which conflict reigns - 'there never will be such a harmony [...] in the city' ${ }^{39}$ the corresponding notion of justice needs to be a procedural one, he claims. The age-old and universal principle of hearing both sides, the principle of audi et alteram partem, is this notion. Hampshire admits that conflict may also involve procedural questions, but 'the framework of such a dispute, if it handled with justice and fairness, is still the universal principle of adversary argument'. ${ }^{40}$ Is the

32 Matt Sleat, 'Coercing Non-liberal Persons. Considerations on a More Realistic Liberalism,' European Journal of Political Theory 12 (2013): 347-367.

33 Newey, After Politics, 52.

34 Bernard Williams, In the Beginning Was the Deed: Realism and Moralism in Political Argument (Oxford: Princeton University Press, 2005), 2.

35 Williams, In the Beginning Was the Deed, 3.

36 Williams, In the Beginning Was the Deed, 5.

37 Williams, In the Beginning Was the Deed, 5. This definition of politics cannot be considered uncontroversial. See the comment by Newey concerning the definition of politics above.

38 Hampshire, Justice is Conflict, 32.

39 Hampshire, Justice is Conflict, 18.

40 Hampshire, Justice is Conflict, 37. 
result decisionism ${ }^{41}$ Is, in the absence of a substantial independent standard of justice, any outcome of procedures just, as long as the procedures themselves are just? Although the main political realist argument appears to push in this direction, there is agreement among realists that procedures and practices of justification restrict what can be considered as correct outcomes of political procedures. '[L] egitimating discourse puts real limits on what political actors can think and do'. ${ }^{42}$ The rhetorical notion of public reason presented in the fourth section of this article may enhance our understanding of this process of limitation. ${ }^{43}$

\section{Consensus and compromise}

Once the well-ordered society is rejected as a proper starting point for political theory, rational consensus between reasonable liberal citizens is no longer viewed as an attainable or even desirable aim of politics. Realists point to compromise instead. ${ }^{44}$ Compromise is desirable to the extent that the positions of the parties to the conflict can still be recognized in the compromise. The reflection of a society's prevailing views within a particular compromise suggests a just decisionmaking process, Hampshire explains, while the liberal consensus, on the other hand, pushes minority views out of sight as unreasonable. Compromise need not be the 'shabby' result it is often thought to be by 'those who are intent on a specific form of substantial justice'. 'A smart compromise is one where the tension between contrary forces and impulses, pulling against each other, is perceptible and vivid, and both forces and impulses have been kept at full strength, with the tension of the Heraclitean bow'. ${ }^{45}$

In sum: If Rawls' basic assumption of a well-ordered society is abandoned, political liberalism reappears, its realist critics argue, as a theory that misunderstands politics, inadequately conceptualizes disagreement, silences minorities, and is moralist. The rejection of this key assumption of liberal thought provides in this reconstruction the foundation on which the political realist framework is built - a framework to which I add in this article a rhetorical notion of public reason.

\section{The role of a notion of public reason}

The elements of a political realist framework are now in place. Our objective is to develop a notion of public reason that can be added to this framework. To do that, we must first specify what to look for. What is, in general, a notion of public reason? The difficulty is that such a general notion has not yet been constructed. All we can be familiar with is a liberal understanding of public reason, as it is developed within Rawls' political liberalism, where this notion is expressed in a

41 See on this point the discussion in Newey, 'Just Politics'.

42 Newey, 'Just Politics,' 167.

43 See section 4.3.

44 For instance, the special issue of Critical Journal of International Social and Political Philosophy 16(4) (2013), and John Horton, 'Realism, Liberal Moralism and a Political Theory of Modus Vivendi,' European Journal of Political Theory 9 (2010): 431-448. 
very detailed manner. I start in this section with this liberal notion and construct from it a more general notion of public reason.

In the first section, we have already explained why free and equal citizens demand that laws are justified in public reason. We need to indicate with more precision now what this notion is (1) and what it does in political liberalism (2 and 3).

1. Liberal public reason does not imply agreement in all matters of justice. What is it that we agree about, according to the liberal understanding?

'Close agreement is rarely achieved and abandoning public reason whenever disagreement occurs in balancing values is in effect to abandon it altogether. Moreover [..], public reason does not ask us to accept the very same principles of justice, but rather to conduct our fundamental discussions in terms of what we regard as a political conception. We should sincerely think that our view of the matter is based on political values everyone can reasonably be expected to endorse. For an electorate thus to conduct itself is a high ideal the following of which realizes fundamental democratic values not to be abandoned simply because full agreement does not obtain. A vote can be held on a fundamental question as on any other; and if the question is debated by appeal to political values and citizens vote their sincere opinion, the ideal is sustained'. ${ }^{46}$

The excerpt makes clear that liberalism asks us to use those reasons in our political argumentation that other citizens can accept. It does not mean that other citizens will be convinced of the conclusions these arguments are meant to support. Others may find different political arguments more compelling and may therefore arrive at different conclusions. This is to be expected. What matters is that these arguments can reasonably be accepted or, alternatively, that these cannot reasonably be rejected. ${ }^{47} \mathrm{~A}$ variety of arguments may be within the limits of liberal public reason. The idea of liberal public reason is that certain arguments and consequently also certain conclusions fall outside of it, because these cannot possibly be accepted by all citizens, understood as free and equal. This is already adequately explained by Kant:

'[Dieser Vertrag (contractus originarius)] ist eine bloße Idee der Vernunft, die aber ihre unbezweifelte (praktische) Realität hat: nämlich jeden Gesetzgeber zu verbinden, da $\beta$ er seine Gesetze so gebe, als sie aus dem vereinigten Willen eines ganzen Volks haben entspringen können, und jeden Unterthan, so fern er Bürger sein will, so anzusehen, als ob er zu einem solchen Willen mit zusammen gestimmt habe. Denn das ist die Probirstein der Rechtmäßigkeit eines jeden öffentlichen Gesetzes. Ist nämlich dieses so beschaffen, da $\beta$ ein ganzes Volk unmöglich dazu seine Einstimmung geben könnte (wie z.B. da $\beta$

46 John Rawls, Political Liberalism, 241.

47 See Thomas Scanlon, What We Owe to Each Other (Cambridge, Mass.: Belknap Press, 2000), chapter 5 . 
eine gewisse Klasse von Unterthanen erblich den Vorzug des Herrenstandes haben sollten), so ist es nicht gerecht; ist es aber nur moglich, da $\beta$ ein Volk dazu zusammen stimme, so ist es Pflicht, das Gesetz für gerecht zu halten: gesetzt auch, da $\beta$ das Volk jetzt in einer solchen Lage, oder Stimmung seiner Denkungsart wäre, daß es, wenn es darum befragt würde, wahrscheinlicherweise seine Bestimmung verweigern würde'. ${ }^{48}$

Rawls' quote above presupposes that citizens will be able in general to distinguish between political and non-political argumentation, between those arguments that fall within and those that fall outside public reason. Some liberals argue that if this distinction is not clear, there cannot be a moral duty to use public reason. ${ }^{49}$ Others have argued that this ignores the fact that democracy is always viewed as deliberative by contemporary liberals, with the implication that citizens discussing laws or proposals need to be thought of as willing to learn from others and as prepared to revise their positions in the light of this learning process. There is no reason why this learning process may not also concern the question which reasons can be acceptable to others. ${ }^{50}$

2. Public reason is used first to explain disagreement and the possibility of discussion between liberal citizens. Political argumentation is possible in a fragmented and divided society because citizens who view each other as equal and free will insist that the laws governing their conduct are based on reasons all citizens can accept - they need to be able to view themselves as the authors of those laws (or else their equal freedom is at stake). This means that these laws have to be discussed against the background of this picture of equal freedom for all, this background ideal of democratic justice. Political argumentation involves, essentially, the interpretation of this liberal, Kantian ideal. So regardless of the prevailing and clashing comprehensive doctrines concerning what is a good and valuable in life, citizens are able to argue with each other precisely because they are assumed to have, besides such a comprehensive doctrine, a certain political conception of justice, a specific interpretation of this ideal. These political conceptions of justice will be different to a certain extent, but all reasonable citizens, Rawls assumes, will be able to view these reasonable political conceptions of justice as political, i.e., as acceptable to free and equal citizens.

3. The second use is tied to the legitimacy test. Acceptability in the sense defined by Kant above is linked to the idea of free equals, and the idea is that this provides us with a high moral standard in which the equal freedom of all needs to be protected, no matter what. The original position is a model with which to assess

48 See Immanuel Kant, 'Über den Gemeinspruch: Das mag in der Theorie richtig sein, taugt aber nicht für die Praxis,' in Zum ewigen Frieden und andere Schriften, ed. Immanuel Kant (Frankfurt am Main: Fischer Verlag, 2008), 107.

49 Kyla Ebels-Duggan, 'The Beginning of Community. Politics in the Face of Disagreement,' The Philosophical Quarterly 60 (2010), 50-71.

50 I argue that agreement about what are political reasons is no condition of the duty to refer to political reasons in 'Do EU Citizens Have a Duty to Use Public Reason?,' Rechtstheorie 45 (2014), 487-506. 
what free and equal citizens are able to accept. The idea is that what is reasonable can be assessed by each and every one. Given certain starting points - in this case: free and equal citizens - certain outcomes are contrary to reason - are at odds with this idea of equal freedom. Of course, this does not mean that in practice feedback is not possible or that mistakes cannot be made; that would run counter to the idea of deliberative democracy, to the idea of moral learning or the process towards an overlapping consensus which Rawls views as the telos of public reason.

Given these features (1-3) of the liberal notion of public reason, my proposal is now that public reason in general needs to address these same three questions. A specific notion of public reason answers these three questions. The answers may differ from the ones formulated by political liberalism. The first feature of such a notion is that it specifies the range of acceptable or public arguments. In liberalism, arguments are acceptable in so far as these can be accepted by reasonable citizens, citizens respecting each other as equal and free. But this is a specific criterion of acceptability. Others can be proposed. What is important is that a notion of public reason defines a criterion of acceptability. Features (2) and (3) correspond to the two functions of such a criterion. The first is that public reason is able to explain how political argumentation is possible. Within the liberal notion of public reason, basic agreement explains how argumentation is possible. Other explanations are possible. If the notion is to be realist, it obviously cannot explain political argumentation in terms of background consensus, because such a consensus is not taken for granted by the realist. The third feature is that public reason can be used to demarcate between correct and incorrect public argumentation. This is the application of the criterion of acceptability.

\section{Rhetoric, dialectic and public reason}

So what we look for in classical texts on rhetoric and dialectic is a notion of public reason, and this is a notion that (1) specifies a class of acceptable arguments, (2) explains how political argumentation is possible, and (3) formulates a standard with which to differentiate in practice between acceptable and inacceptable arguments. Given this objective, I need to reflect in this section on Aristotle's texts on rhetoric and dialectic. The reason is that Aristotle has advanced a notion in these texts of acceptable or reputable views or 'ta endoxa'. ${ }^{51}$ Again, the argument here is not that Aristotle is a political realist. The claim defended in this section is much more restricted: that from Aristotle's texts on dialectic and rhetoric a notion of public reason can be reconstructed. In the final section, I conclude that this notion is not incompatible with the political realist framework as presented in section 2 .

51 See Robin Smith, Aristotle. Topics Books I and VIII, Translated with a Commentary (Oxford: Oxford University Press, 1997), 42. In this section, I use Bekker numbers, to enable readers to locate the relevant passages in their translation of Aristotle's works. 
1. I start here with the first feature of a notion of public reason and that is that it must indicate a class of public or acceptable reasons. To understand correctly what Aristotle means with ta endoxa or 'acceptable things' or 'reputable things', ${ }^{52}$ let us start with the distinction he draws between the reasoning of the scientist, about necessary relations in nature, and the reasoning about human affairs in front of a public, by the lawyer or politician. Where the scientist demonstrates the truth of a conclusion through logical deduction from true premises, the orator works from premises that are acceptable instead. What is acceptable? 'Those things are true and primary which get their trustworthiness through themselves rather than through other things [...]. Those are acceptable, on the other hand, which seem so [i.e., trustworthy, persuasive ${ }^{53}$ ] to everyone, or to most people, or to the wise - to all of them, or to most, or to the most famous and esteemed' (100 b 18-23). Whether we find Aristotle's analysis of scientific reasoning convincing or not, interesting for our discussion is that in public reasoning, views are acceptable in so far as they seem right or true ${ }^{54}$ to people. The idea conveyed here is that where sciences deal with necessary relations between things that 'get their trustworthiness through themselves', arts of public argumentation about public affairs, on the other hand, deal with 'things' that get their trustworthiness through people (everyone, most people, the wise, etc.). The things that play a role in human affairs are evidently valuable or recommendable or acceptable, not because of a quality in those things themselves, for each and every one to touch, taste, smell, see, or hear, but because people believe they are correct.

This has important implications for Aristotle's notion of argumentation or deliberation, because, since people attach trustworthiness to the things people need to deliberate about (war and peace, for instance) and a polis consists of people of 'different kinds' (1261 a 23, emphasis added), we may expect disagreement about these things (war or peace with Sparta?). And indeed, Aristotle explains that argumentation deals with problems 'about which people either have no opinion, or the public think the opposite of the wise, or the wise think the opposite of the public, or each of these groups has opposed opinions within itself' (104 b 4-6).

What is the meaning of endoxa in such circumstances of argumentation? Does endoxa imply that there is a standard independent of politics, with which to assess the acceptability of political positions? No. The analysis above supports the conclusion that acceptability or reputability is a relative concept. ${ }^{55}$ What views are reputable cannot be determined prior to or independent of actual practices of political argument. Again, what is acceptable or reputable is what the many or the (1996)), 57.

53 My addition. Trustworthiness is a translation of pistis. See Smith, Aristotle. Topics, 46. See also Höffe, Aristoteles, 56-61.

54 Höffe writes in this respect about opinions viewed as true, 'für wahr gehalten', Höffe, Aristoteles, 57.

55 Smith, Aristotle. Topics, 42: 'As I interpret it, it is in fact a relative term: a proposition is endoxos with respect to some definite group of persons, whether it be the public generally, or the community of experts, or someone famous'. For a similar view, see Höffe, Aristoteles, 56-7. 
wise or some smaller group within these two are convinced of. 'That which is persuasive is persuasive in reference to someone' (1356 b 11), Aristotle explains.

So does this mean that the class of acceptable views is the class of actually accepted views? Those opinions are acceptable that are prevalent in society? Yes. In the Nicomachean Ethics, Aristotle confirms this view of opinions as endoxos in the sense of 'prevalent'. But this is not all. Aristotle adds something to the concept: those views are endoxos that 'seem to have some reason'. ${ }^{56}$ In the Eudemian Ethics, we find a clue, following Jonathan Barnes, for understanding what Aristotle may have meant with this phrase, when he introduces opinions of philosophers on the topic of eudaimonia:

'It would be superfluous to examine all the opinions about happiness that find adherents. Many opinions are held by children and by the diseased and mentally unbalanced, and no sensible man would concern himself with puzzles about them; the holders of such views are in need, not of arguments, but of maturity in which to change their opinions, or else of correction of a civil or medical kind (for medical treatment is no less a form of correction than flogging is). Similarly, neither need we examine the views of the many; they speak in an unreflective way on almost every topic, most of all when they speak about this; only the opinions of reasonable men should be examined; it would be strange to present argument to those who need not argument, but experience' (1214 b 27-1215 a 4).

The philosophical reflection upon eudaimonia is not something many ordinary people will be capable of, Aristotle assumes here. Their views cannot be 'mature', simply because 'the many' have not properly thought about the topic. The views are not yet mature views - not necessarily wrong views but in an important sense not yet views at all. 'Seem to have some reason' apparently needs to be taken in the literal sense: supported by reasons, considered. Höffe also recognizes this second aspect when he stresses that views are endoxos if they are 'wohlbegründet'. ${ }^{57}$ The views of children or ill people are not yet views supported by argument, as are the views of 'the many', at least concerning this topic.

Let me summarize this part briefly: the acceptable or reputable opinions or views are views that are both prevalent and rational, in the meaning of well-considered. These reasons need not be reasons that reasonable citizens cannot reasonably reject, to contrast it with the liberal standard. Aristotle takes disagreement in matters concerning human affairs seriously. Disagreement is a condition of public argumentation. Public affairs are the affairs about which the many and the wise may not only have 'opposite' opinions. 'Each of these groups' may even have 'opposed opinions within itself' (104 b 4-6). 
2. How can argumentation be possible, let alone effective, in these circumstances of disagreement? None of the acceptable views are necessarily acceptable to all. Some of the views may be acceptable only to the wise while others may be regarded as reputable in the eyes of the many. The main rhetorical advice in this respect is that the orator has to adapt the speech to the audience. While in a scientific treatise, the public need not play a part at all - the premises on which it is built can be empirically verified by each and every human being - in political argumentation a specific audience needs to accept the specific reasons as correct or true, to convince it of the conclusion drawn from them. In a discussion - at least in the dialectical variant with which Aristotle is familiar; a discussion by two, a questioner and an answerer - this is done by questions. Dialectic instructs the speaker to ask the opponent (an audience of one) to accept the premises, one by one, from which the speaker eventually hopes to refute the opponent's position. In a speech before a large audience, the orator cannot ask for acceptance in every step of the argument. He needs to predict what his audience will accept. 'Rhetoric will not consider what seems probable in each individual case, for instance to Socrates or Hippias, but that which seems probable to this or that class of persons' (1356 b 11). Rhetoric instructs the speaker how to estimate which reasons are useful in a certain kind of case, for a certain kind of audience. What rhetoric and dialectic share is that it is this cooperation between speaker and audience, in both oratory and discussion, that explains how political argumentation is possible. Cooperation is here: that a speaker argues from reasons accepted by the audience. The audience may be the opponent in a public discussion or the majority of citizens in the case of a public speech. In both instances, the fact that there is disagreement in society, that, say, different views of justice prevail, does not affect the possibility of argumentation. In a dialectical refutation, the questioner and answerer always deal with the answerer's views (roles may turn), and in a public speech, the orator deals with the views he thinks will persuade the majority of citizens. So always a particular view is selected and tested in the context of a discussion or against the background of multiple speeches. Political argumentation proceeds in this model by testing the different views, one after the other. In proceeding in this way, political argumentation is possible in circumstances of disagreement.

While it is this cooperation between speaker and audience that explains why argumentation in circumstances of disagreement is possible, it is the competition between speakers or, to be more precise, the competitive setting of political speech and political discussion, on the other hand, that is designed to make argumentation in circumstances of politics effective. The arts of rhetoric and dialectic were developed against the background of Greek polis life, which included public discussions in smaller circles and political and juridical speeches before larger audiences. Rhetorical manuals take the competitive setting as a given, a setting where multiple orators deliver their speeches before an assembly and where oratorical practice includes the refutation of the opponent's argument. In dialectical discussion, the competition takes a distinct shape. Dialectic is a game of questions and answers for two, a questioner and an answerer. The task of the ques- 
tioner is to collect premises accepted by the answerer and deduce from these premises a conclusion. The answerer is forced by logic to accept the conclusion, if the deduction is valid and constructed from accepted premises. The art of this type of discussion is applicable in a variety of contexts. ${ }^{58}$ In the context of education, for instance, the professor may use discussion as a way to teach a student a certain position or theory. The student is not viewed as an opponent, of course (159 a 30). The aim is understanding, not victory. In a political context, however, dialectical discussion is highly competitive. The questioner's aim may be to refute the thesis of the answerer, i.e., 'to lead the argument so as to make the answerer state the most unacceptable of the consequences made necessary as a result of the thesis' (159 a 18-25). The answerer is only forced (forced by logic) to give up his thesis when he accepts premises from which the questioner can deduce the opposite of (or something different from) the answerer's position. Therefore, as long as the answerer avoids inconsistency in his reasoning, he is not logically forced to abandon his position. This makes it very difficult for participants with more or less equal reasoning capacities and with positions equally defensible (!) to force the other to give up his position. This explains why in the competitive variant it is anticipated that a clear victory is not within reach. This variant's goal becomes instead something that is attainable and recognizable at the same time: 'The questioner must at all costs appear to be inflicting something on the answerer, while the answerer must appear not to be affected' (159 a 31-32). The stress on appearance suggests the presence of an audience, selecting the winner. ${ }^{59}$ This competitive variant of dialectical argumentation is not too different from the type of competitive political discussion we are familiar with. ${ }^{60}$

The conclusion of this second part is that the rhetorical notion of public reason, which defines public views as prevalent and considered opinions, explains why argumentation is possible in circumstances of disagreement (through cooperation between speaker and audience) and also why it can be made productive in such circumstances (through competition before a judging audience). Notice that the cooperative-competitive setting of political argumentation in speech and discussion also explains why arguments need to be both prevalent (in order to gain support from a majority or an opponent) and rational (in order to survive refutation in speeches by rivals and discussions with opponents). In section 4.1, we highlighted prevalence and rationality as the two components of the rhetorical notion of public reason. Now that these components are situated in practices of argumentation (discussion and oratory), it has become clear how political argumentation is possible and can be effective in circumstances of radical disagreement.

58 See also Höffe, Aristoteles, 58-9.

59 Smith, Aristotle. Topics, 128.

60 See Bertjan Wolthuis, 'Het spelkarakter van het parlementaire debat,' Rechtsfilosofie en Rechtstheorie 36 (2007): 12-33 and Bertjan Wolthuis, 'Objective Rules of Argumentation,' in Objectivity in Law and Legal Reasoning, ed. Jaakko Husa and Mark Van Hoecke (Oxford: Hart Publishing, 2013), 109-30. 
3. The third feature of a notion of public reason is that it proposes a criterion with which to differentiate between acceptable and inacceptable arguments. The criterion provided by the rhetorical notion of public reason reconstructed above is that views are acceptable if these are prevalent and considered. Viewed in isolation (section 4.1), this criterion may perhaps not seem to amount to much, especially in comparison with its liberal rival. A view is acceptable if all or many or the wise or a smaller group within each of these groups believe it is correct or true. A view is considered if it is accompanied by reasons. Viewed in the context of political speech and discussion (section 4.2), however, we gain a better understanding of how 'legitimizing discourse', to use Newey's words, 'puts real limits on what political actors can think and do' (section 2, Legitimacy). The idea is that political actors who want to exert influence not only need to draw on what substantial parts of the citizenry find convincing, the views selected also need to be defensible. Both aspects limit what the politician can say and propose, as is illustrated by the suboptimal cases of the populist and technocratic politician. The first ignores the aspect of rationality, the latter that of prevalence among large parts of the electorate. The idea is clear: the practices of competition and contestation in both speech and dialogue settings work as filters. If these practices are taken seriously, and views are tested and win a majority, these views are both prevalent and rational or endoxos. The views need not be legitimate from a liberal point of view though. As explained in the previous section, the liberal test of 'not reasonable to reject' is a different, substantial test. The rhetorical test includes a rationality test but not a substantial one. The rhetorical rationality test is whether the position is consistent, not whether it is consistent with the substantial liberal ideal of society as a just system of cooperation between free and equal citizens.

The rhetorical notion of public reason, we conclude, is a notion of public reason, as defined above (section 3): it indicates what reasons or views are public or acceptable, it explains how public argumentation is possible, and it differentiates between acceptable and inacceptable arguments.

\section{Conclusion}

The final question to answer is this: Is the rhetorical notion of public reason compatible with the political realist framework? The answer follows from a confrontation of the conclusions of sections 2 and 4 . In section 2, the political realist position is represented as a series of interrelated criticisms of John Rawls' political liberalism, with the rejection of the assumption of a well-ordered society as its corner stone. Political realism rejects the assumption that citizens accept the principles of justice ordering their society. It does not take this general level of agreement for granted. This disrupts the liberal position, which departs from this point. It disqualifies it as moralist and proposes alternative aims of politics: compromise instead of consensus, procedural justice instead of substantial justice, and so on. 
That the rhetorical notion of public reason is compatible with this picture of a fragmented society, torn between irreconcilable notions of justice, is supported by the analysis presented in the previous section. The rhetorical notion of public reason does not assume agreement about what are political or public views, positions, or reasons. Aristotle acknowledges that argumentation about human affairs concerns problems 'about which people either have no opinion, or the public think the opposite of the wise, or the wise think the opposite of the public, or each of these groups has opposed opinions within itself' (104 b 4-6).

It is still meaningful to talk in such circumstances of public reason. Politicians, citizens have to rely on reputable, acceptable views. Those views are acceptable that all or the many or the wise think are correct. There is no agreement assumed in this relative notion of acceptability. It does not beg the question legislators answer in the circumstances of politics, to use Waldron's words. It does not evade politics.

Views cannot count as acceptable if they are not based on reasons, if they cannot survive the consistency tests to which they are put in dialectical and oratorical discussions. No substantial standards are incorporated in this view of rationality; no substantial notion of a reason is presupposed. The notion is compatible with contemporary political realism and opposed to the liberal doctrine, according to which the reasonably acceptable is linked to the ideal of equal freedom for all. The liberal notion of reason is a substantial one, while the rhetorical notion is not. The possibility of compromising the democratic notion of justice may perhaps not be likely if the filters of prevalence and rationality in oratory and discussion function properly. But it is not acceptable for the Kantian liberal that this realist notion of public reason leaves this possibility theoretically open. ${ }^{61}$

61 See on this topic: Rainer Forst, 'Die normative Ordnung von Gerechtigkeit und Frieden' in Kritik der Rechtfertigungsverhältnisse. Perspektiven einer kritischen Theorie der Politik, ed. Rainer Forst (Frankfurt am Main: Suhrkamp, 2011). 